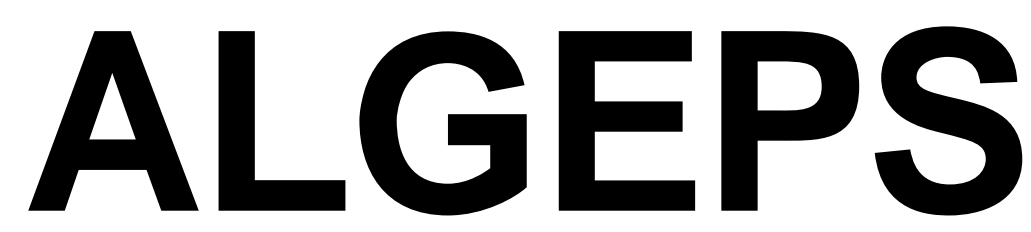

REVISTA DE GEOLOGIA, SÈRIE B no 636 - Juny del 2013

\title{
RECORREGUT DE RECERCA GEOLÒGICA I MINERALÒGICA PER LES COMARQUES DEL BERGUEDÀ I DE LA CERDANYA: DES DE GUARDIOLA DE BERGUEDÀ A LA POBLA DE LILLET, CASTELLAR DE N'HUG, A LA MOLINA I A ALP
}

Josep M. Mata-Perelló i Joaquim Sanz Balagué 


\section{RECORREGUT DE RECERCA GEOLÒGICA I MINERALÒGICA PER LES COMARQUES DEL BERGUEDÀ I DE LA CERDANYA: DES DE GUARDIOLA DE BERGUEDÀ A LA POBLA DE LILLET, CASTELLAR DE N'HUG, A LA MOLINA I A ALP / 15 DE SETEMBRE DE 2012}

Per Josep M. Mata-Perelló i Joaquim Sanz Balagué

\section{ADVERTIMENT PREVI}

Com en altres recorreguts de RECERCA GEOLÒGICA I MINERALÒGICA ..., si es disposa del temps suficient, poden efectuar-se passant per totes les parades i filloles. En cas contrari, recomanem prescindir de les anomenades PARADES - CONDICIONALS.

També recomanem de cercar la informació més adient, sobre els trams a recórrer mitjançant camins de terra, o de pista.

Per d'altra banda, recomanem tenir una cura extrema de la NATURA, evitant qualsevol forma d'agressió sobre ella, o de fer-n hi un mal ús del que en ofereix la nostra mare Terra.

\section{BREU INTRODUCCIÓ}

En aquesta ocasió, el recorregut del present itinerari discorrerà, en la seva totalitat pel Sistema Pirinenc. Dintre d'aquest, deambularà per dos dels seus sectors més representatius: en concret pel Mantell del Cadí, i per les immediacions de la zona dels anomenats Apilaments Antiformes del Freser; tot i que també es passarà, a l'ini del recorregut, i de cantonada, pel Mantell del Pedraforca Inferior.

Així, el recorregut començarà a la zona de contacte, entre el Mantell del Cadí (molt a prop de la seva vorera septentrional, amb el Mantell Inferior del Pedraforca. I, tot seguit, el recorregut s'endinçarà per entre els afloraments situats dintre del Mantell del Cadí.

Tot seguit, i poc després d'arribar a la comarca de la Cerdanya, el recorregut passarà per les immediacions de la zona dels Apilaments Antiformes de la Zona Axial, tot i que no arribarà a entrar. Finalment, s'entrarà a la Depressió de la Cerdanya, per on finalitzarà el recorregut de l'itinerari.

Per d'altra banda. aquest recorregut haurà transitat per dues comarques: s'haurà iniciat a la del Berguedà, per a finalitzar a la de la Cerdanya, tot i que molt a prop de la primera. 


\section{OBJECTIUS FONAMENTALS D’AQUEST ITINERARI}

Es concretaran en diversos aspectes, geològics $\mathrm{i}$ mineralògics que apuntarem a continuació, d'acord amb la direcció del recorregut de l'itinerari:

1.- Observació i estudi dels afloraments del Sistema Pirinenc, tant dels que corresponen al Mantell del Cadí; (com des de lluny dels Apilaments Antiformes del Freser) que anirem trobant al llarg de tot el recorregut de l'itinerari; així com dels materials del Mantell Inferior del Pedraforca, que tallarem exclusivament a les primeres aturades del recorregut.

2.- Observació i estudi dels materials paleozoics (del Silurià, Devonià, Carbonífer i Permià), que formen part dels relleus del Mantell del Cadí., i que tallarem pels voltants de Castellar de N’Hug i del Coll de Creueta.

3.- Estudi dels materials mesozoics, que formen part del Mantell del Cadí, i també del Mantell Inferior del Pedraforca, i que tallarem als trams centrals de l'itinerari. Aquests materials del pertanyen al Triàsic, al Juràssic i al Cretàcic.

4.- Observació i estudi del materials cenozoics (fonamentalment de 1 Eocè), que formen part del Mantell del Cadí. Aquests materials es distribueixen entre les següents formacions: Formació del Cadí, Formació Sagnari, Formació Banyoles, Formació Corones, Formació Vallfogona, Formació Campdevànol i Formació Armàncies i Formació Bellmunt. Fonamentalment, les tallarem entre la Pobla de Lillet i Castellar de N'Hug. També cal fer esment dels materials neògens que tallarem pels voltants d’Alp, a la Depressió de la Cerdanya.

5.- Estudi i descripció de les relacions i els contactes existents entre les tres unitats acabades d'esmentar al paràgrafs anteriors i entre els materials que les constitueixen.

6.- Observació i reconeixement dels materials volcànics, si s'escau, que es troben entre els afloraments del Permià i del Carbonífer (dintre del Mantell del Cadí).

7.- Reconeixement de diverses mineralitzacions, que anirem veient al llarg de tot el recorregut, com les següents:

7A) de les mineralitzacions diagenètiques de QUARS, situades entre els materials triàsics del Keuper del Mantell Inferior del Pedraforca, que trobarem prop de Guardiola de Berguedà i de la Pobla de Lillet (al Berguedà),

7B) de les mineralitzacions evaporítiques guixoses, les quals es localitzen entre els nivells eocènics de la Formació Campdevànol, situats entre el Mantell del Cadí, i que s'exploten al terme de la Pobla de Lillet (Berguedà); així com al terme veí de Gombren (de la comarca del Ripollès). Dintre d’aquesta darrera comarca, també els veurem a Campdevànol,

8.- Observació de les explotacions mineres realitzades amb les mineralitzacions anteriors. Tanmateix s'observaran d'altres, que s'aniran trobant al llarg del recorregut. En especial de les instal-lacions relacionades amb les explotacions de petroli. Per les immediacions de la Pobla de Lillet al torrent de Riutort.

9.- Observació de la degradació mediambiental, produïdes com a conseqüència de les explotacions mineres.

10.- Observació dels diferents indrets relacionats amb el nostre Patrimoni Geològic $i$ 
Miner, que anirem trobant al llarg del present itinerari.

\section{ANTECEDENTS BIBLIOGRÀFICS}

En relació a aquest recorregut, existeixen pocs antecedents, normalment relatius a trams parcials del recorregut de l'itinerari. Entre ells, farem esment de MASACHS et altri (1981); així com a diversos treballs nostres: MATA-PERELLÓ (1995, 1996a., 1996b, 1997 i 2007).

També farem esment de dos treballs més, on hi ha itineraris coincidents parcialment amb el present. Es tracta de: MATA-PERELLÓ i FONT SOLDEVILA (1995), i de MATAPERELLÓ i SANZ BALAGUÉ (1991). Ara bé, en tots els casos, es tracta d'antecedents moll marginals, en relació amb el recorregut de l'itinerari.

Pel que fa a les mineralitzacions que veurem en aquest itinerari, cal dir que ja estat prèviament descrites per nosaltres en un altre treball (d'àmbit general referit al conjunt de Catalunya), al qual ens remetem. Es tracta de MATA-PERELLÓ (1991). També es poden trobar antecedents a MATA-PERELLÓ (1984).

I pel que fa a l'estructura geològica, ens remetérem a RIBA et altri (1976), i a GUIMERÀ et altri (1992). Igualment, es pot fer esment de les recents publicacions de l'TTGME (1991a, 1991b i 1994).

Tots aquests treballs, figuren convenientment referenciats, per estricte ordre alfabètic, dintre de l'apartat dedicat a les REFERÈNCIES BIBLIOGRÀFIQUES, al qual ens remetem.

\section{RECORREGUT DE L'ITINERARI}

El recorregut del present itinerari s'iniciarà prop de la localitat de Guardiola de Berguedà, dintre de la comarca del Berguedà per on es faran les primeres aturades. Tot seguit s'anirà cap a la Pobla de Lillet. En aquest tram s'efectuarà una nova aturada, i unes altres prop de la segona població esmentada.

A continuació, el recorregut es dirigirà cap al trencall de la pista-carretera que sén va cap a Sant Jaume de Frontanyà. Aquí caldrà fer una aturada, sobre un aflorament dels nivells del Keuper. Tot seguit, i després de fer la parada anterior, caldrà retornar a la Pobla de Lillet, des d'on es continuarà cap al Clot del Moro (on es farà una nova aturada), i cap a Castellar de N’Hug, on es realitzarà una altra parada.

Després, des de la població anterior, el recorregut de l'itinerari s'encaminarà cap al Coll de la Creueta, per la carretera que sén va cap a la Molina, i cap a Puigcerdà En arribar a l'esmentat coll, es realitzarà una nova aturada dintre del recorregut de l'itinerari, al límit entre les comarques del Berguedà i de la Cerdanya. Després, el recorregut es dirigirà cap a la Molina, des d'on es dirigirà cap a la població d' Alp. En aquest darrer indret, finalitzarà aquest recorregut.

\section{DESCRIPCIÓ DE L'ITINERARI}


En aquest recorregut hem situat, com ja és habitual en tots els altres itineraris de recerca, una sèrie d'ESTACIONS o de PARADES, que anirem veient a continuació. En cada cas, els hi donarem una denominació que podrà correspondre a algun paratge proper.

Per d'altra banda, en cadascuna de les parades, indicarem entre parèntesi el número del "Mapa Topográfico", a escala 1:50.000, on es troba situada la parada considerada. Finalment, cal dir que el recorregut de l'itinerari s'inclourà dintre dels següents fulls: 217 (dit de Puigcerdà), 218 (dit de Molló), 255 (dit de la Pobla de Lillet) i 256 (o de Ripoll).

Així doncs, la relació general de les parades que constitueixen el recorregut d'aquest itinerari, és la següent:

\section{PARADA 1. IMMEDIACIONS DE L'ANTIGA ESTACIÓ DEL FERROCARRIL DE GUÀRDIOLA, (terme municipal de Guardiola de Berguedà, comarca del Berguedà). (Full 255).}

El recorregut s'iniciarà en aquest indret, per on s'efectuarà la primera aturada del recorregut, a tocar la població de Guardiola de Berguedà.

En aquest lloc hi ha un aflorament dels materials del Keuper, constituïts per nivells de guixos i d'argiles. Entre uns i altres es poden trobar bons exemplars de QUARS (de la varietat JACINT DE COMPOSTEL.LA). Tot i que a l'actualitat els que ara es troben no són gaire grans, s'havien trobat exemplars de fins a $2 \mathrm{~cm}$ d'aresta. També es poden trobar abundants mostres de GUIX ROIG; així com freqüents eflorescències d'EPSOMITA i d'HEXAHIDRITA, situades entre els afloraments argilosos, principalment. FOTOGRAFIA 1.

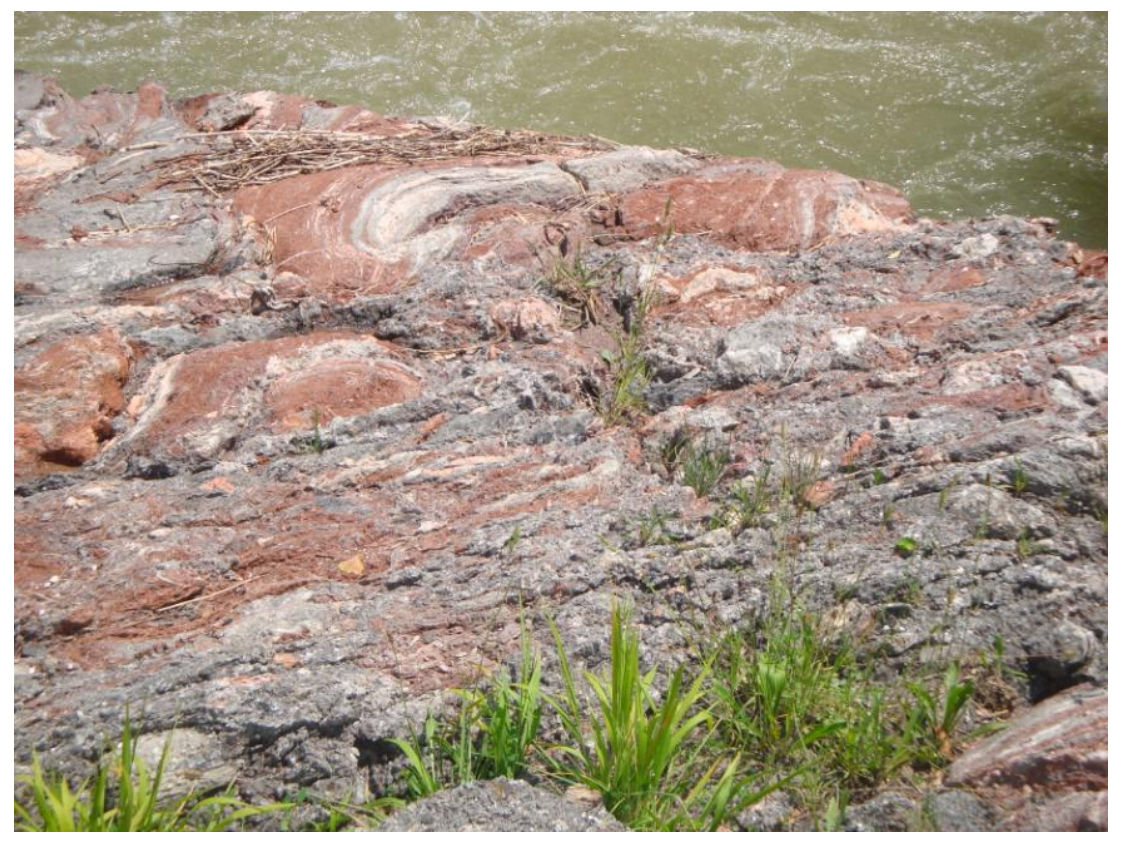

\section{FOTOGRAFIA 1.}

Aflorament dels guixos rogencs del Keuper, a Guardiola de Berguedà

Aquests nivells del Triàsic Superior, es situen a l'encavalcament dels materials mesozoics del Mantell Inferior del Pedraforca (que es troben al Sud), sobre els cenozoics i 
mesozoics del Mantell del Cadí, que es troben al nord. És a dir: l'encavalcament d'un mantell sobre l'altre es situa cap els voltants de Guardiola de Berguedà.

\section{PARADA 2. INSTAL-LACIONS DE L'ANTIC CARREGADOR DE LA MINA}

DE PETROLI DE RIUTORT, (terme municipal de Guardiola de Berga , comarca del Berguedà). (Full 255).

Des de la parada anterior, cal sortir de Guardiola de Berguedà, per tal d'anar cap a llevant, cap a la Pobla de Lillet, (seguint la carretera 'B - 402), Així, ben aviat s'arribarà al pontet sobre el Riutort. Aquí farem una nova aturada, a uns $5 \mathrm{Km}$ de la anterior.

En aquest recorregut, haurem trobat inicialment els materials triàsics esmentats a l'aturada anterior. Tot i així, prop de l'indret de l'aturada, haurem trobat afloraments dels materials cenozoics calcolutitcs, de marcades tonalitats grisenques. Aquests materials pertanyen a la Formació Armàncies. Aquests són els materials que apareixen a l’indret de l'aturada.

En aquest indret hi ha les restes de l'antic carregador de la Mina de Petroli de Riutort. Aquest element forma part del Patrimoni Miner del Berguedà. FOTOGRAFIA 2.

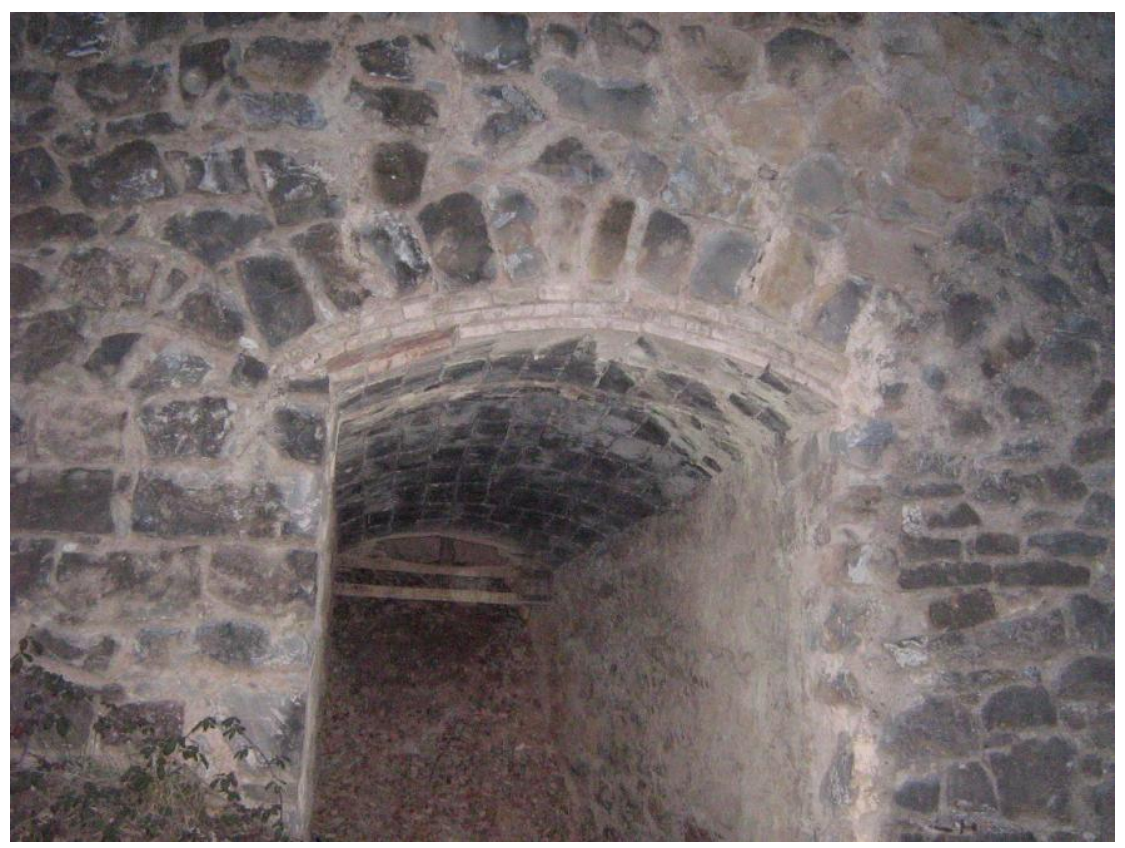

FOTOGRAFIA 2

Carregador de Petroli de Riutort

PARADA 3. MINA DE PETROLI DE RIUTORT, (Gabarrós, terme de Guardiola de Berguedà en la seva divisòria amb el de la Pobla de Lillet, comarca del Berguedà). (Full 255).

Des de la parada anterior, ens caldrà agafar un camí que ascendeix per la riba esquerra. A poc més de 1'5 Km, després de deixar la carretera, es troben les escombreres de l'antiga Mina de Petroli, situada a l'esquerra del camí. Així, des de la parada anterior, haurem recorregut uns 
4 Km més.

En aquest recorregut, haurem trobat exclusivament afloraments de materials marins eocènics, fonamentalment es van tallant afloraments de calcolutites noduloses i gresos grisencs, de la Formació Armàncies. Precisament, aquests darrers materials, són els que es troben a l'indret de l'aturada. En aquest lloc hi ha unes antigues explotacions de petroli, les quals es van realitzar a principis del present segle. El petroli es localitza sobre els nivells calcolutítics de color grisenc acabats d'esmentar, els quals pertanyen a l'Eocè marí, i més concretament a la Formació Armàncies.

Pel que fa a les explotacions consisteixen en una galeria principal, amb una sèrie de galeries travesseres, que formen un interessant entramat. Aquestes darreres galeries tenien la missió de drenar el petroli localitzat a les diàclasis, les quals tallen als materials calcolutítics. FOTOGRAFIA 3.

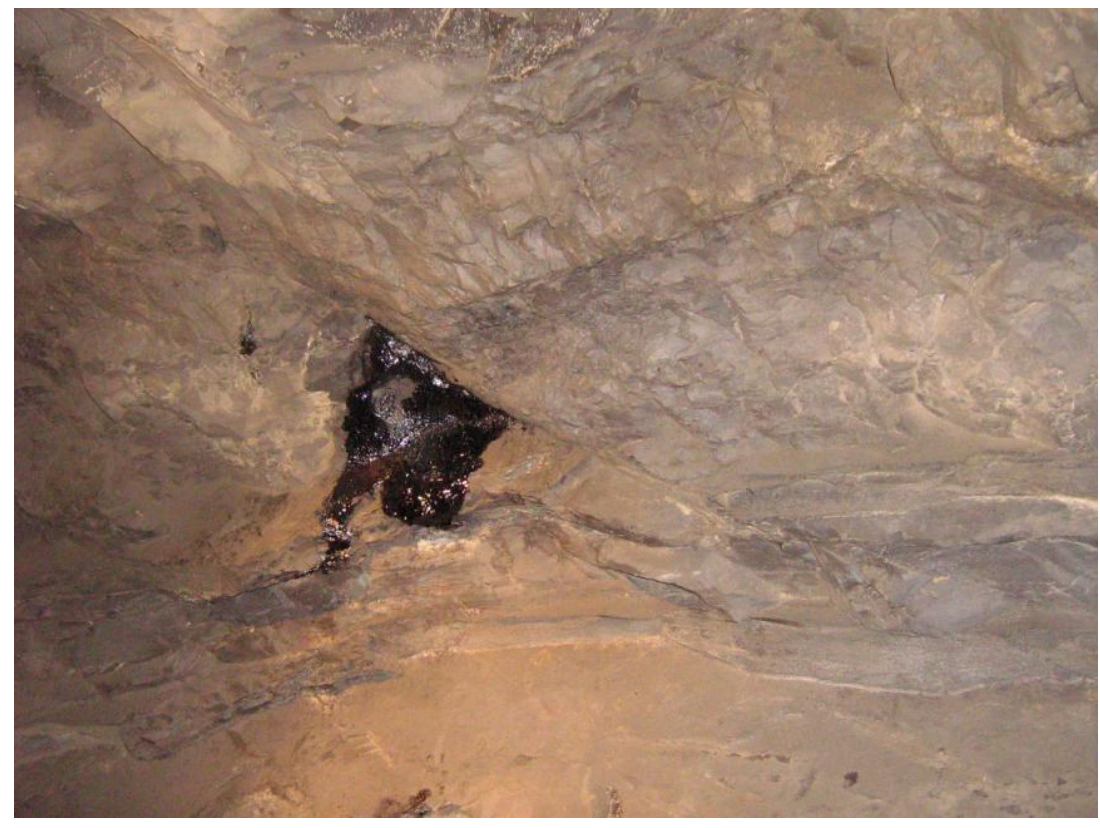

FOTOGRAFIA 3

Petroli, dintre de la Mina de Riutort

\section{PARADA 4. PISTA-CARRETERA DE SANT JAUME DE FRONTANYÀ, (terme de la Pobla de Lillet, comarca del Berguedà). (Full 255).}

Després de fer les aturades anteriors, cal seguir cap a la localitat de la Pobla de Lillet. Aquí ens cal fer una fillola, continuant cap a 1'Est. Així, a uns 5’5-6 Km del poble, es trobarà un camí per la dreta que condueix cap a Sant Jaume de Frontanyà. Caldrà agafar aquest camí, fins arribar a les immediacions del paratge del Guixer, on farem la present aturada.

En tot aquest recorregut de prop de $6 \mathrm{Km}$, des de la Pobla de Lillet, hem anat trobant els nivells eocènics de la Formació Vallfogona, i els de la Formació Campdevànol, constituïts per nivells de calcolutites i de gresos grisencs (amb intercalacions guixoses, entre els materials de la segona formació esmentada). Per d'altra banda, també prop de l'indret de la parada, s'han començat a trobar uns nivells de guixos, els quals pertanyen a la darrera formació esmentada, en 
trànsit cap a la Formació Beuda. Cal dir que tots aquests materials formen part del Mantell del Cadí, per on ens trobem ara circulant.

En aquest indret, també es troben uns nivells de guixos triàsics del Keuper, que contenen abundants JACINTS DE COMPOSTELLA, generalment de dimensions molt reduïdes. Aquests minerals es poden trobar a la mateixa vora del camí.

Aquests darrers materials triàsics es troben en contacte amb els anteriors, però formen part d'un olistostroma, que situa un potent gruix de materials triàsics del Keuper, entremig dels terrenys eocènics del Mantell del Cadí, on ara ens trobem situats. FOTOGRAFIA 4.

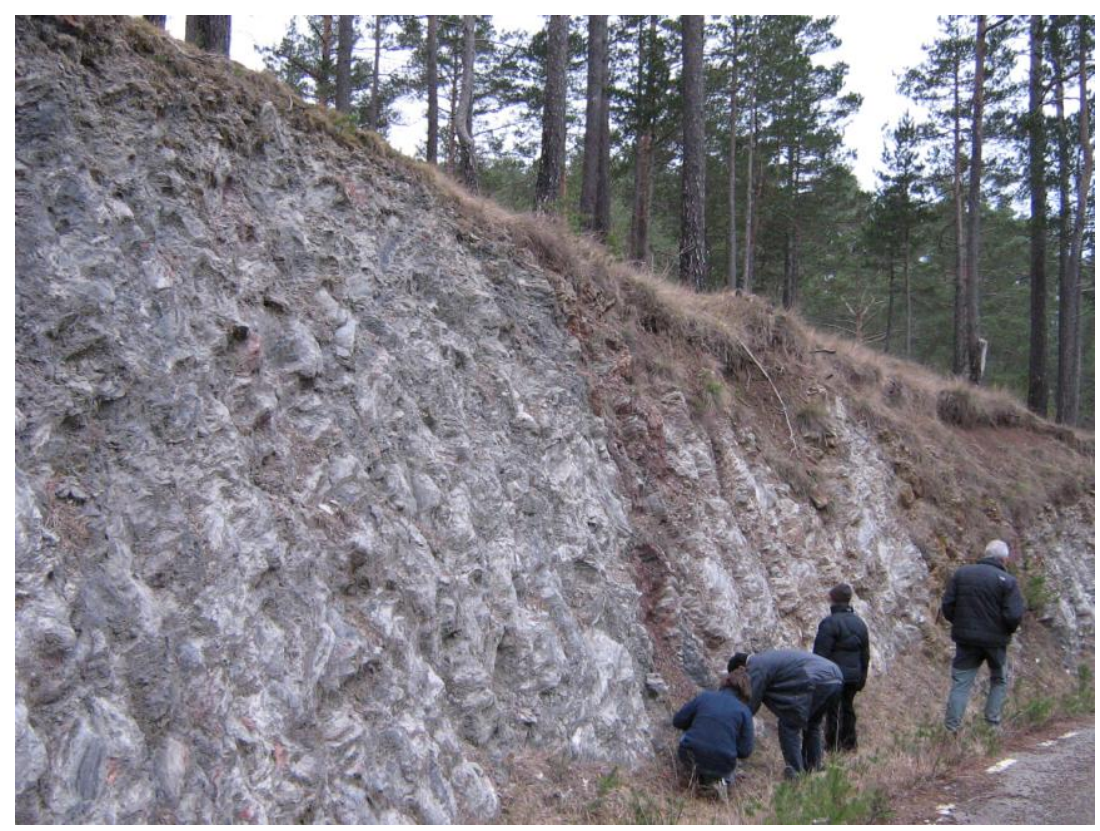

FOTOGRAFIA 4

Els guixos triàsics del Keuper, a la carretera de la Pobla de Lillet a Sant Jaume de Frontanyà

Olistostroma de la Pobla de Lillet

PARADA 5. EL GUIXER, (terme municipal de la Pobla de Lillet, comarca del berguedà). (Full 255).

Des de la parada anterior, cal continuar pel camí, fins a trobar el trencall, que per l'esquerra condueix cap a l'antiga guixera del Guixer. Aquí és on ens caldrà fer la present aturada, després de un recorregut de menys de $1 \mathrm{Km}$, des de la parada anterior.

En aquest breu recorregut, s'han trobat inicialment els nivells del Keuper; però ben aviat s' han tornat a tallar els nivells de guixos esmentats a la parada anterior. Precisament, aquests materials han estat, i estan, en un avançat nivell d'explotació, tant al terme de la Pobla de Lillet, com al veí de Gombreny (Ripollès).

Una mostra d'aquesta explotació es pot veure a la FOTOGRAFIA 5, corresponent a la Guixera de la Pobla de Lillet. 


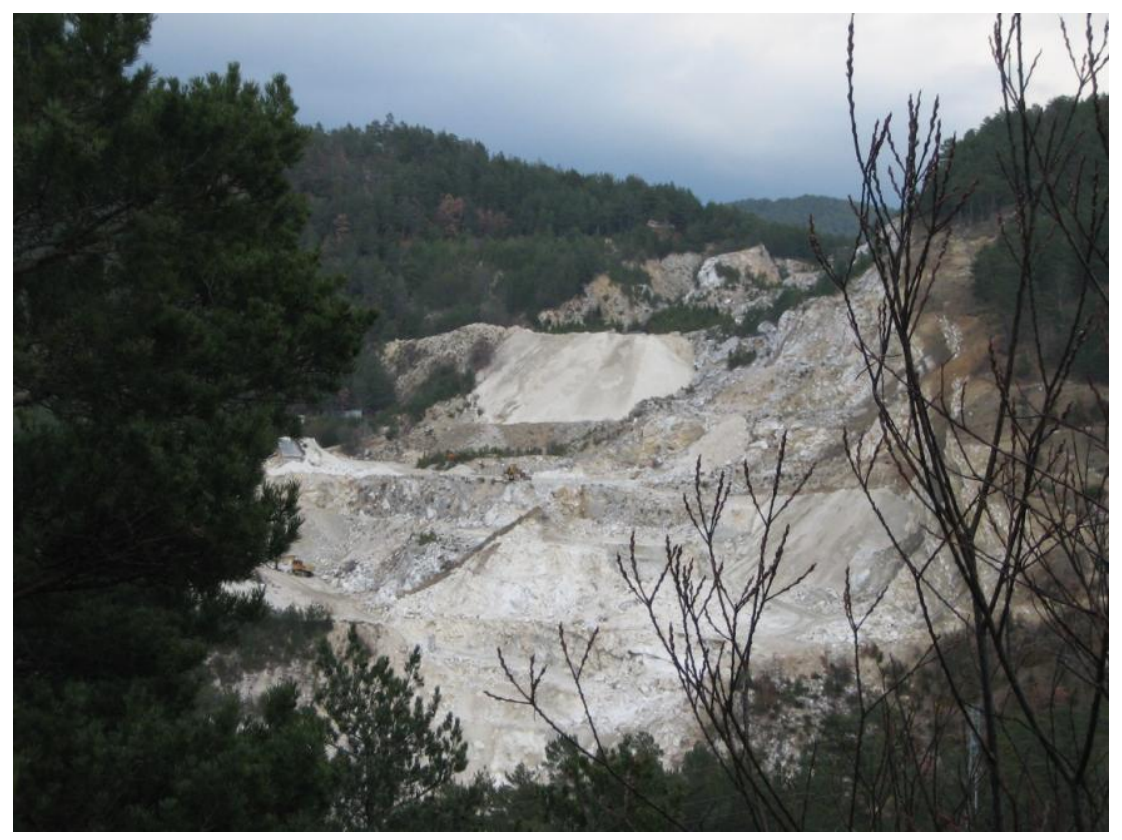

FOTOGRAFIA 5

Guixera de la Pobla de Lillet

\section{PARADA 6. ANTIGA PEDRERA DEL CLOT DEL MORO, (el Clot del Moro, terme de Castellar de N`Hug, comarca del Berguedà). (Full 255).}

Des de la parada anterior, caldrà retornar cap a l'inici de la pista-carretera, i tot seguit cap a la Pobla de Lillet. Després, des d'aquesta, caldrà seguir per la carretera que sén va cap a Castellar de N'Hug. Però, en arribar a les immediacions del Clot del Moro, on ens caldrà fer la present aturada, després d'un recorregut proper als $14 \mathrm{Km}$, des de la parada anterior.

En aquest recorregut, s' han tornat a tallar els materials esmentats a la parada anterior, fins arribar a la Pobla de Lillet. Després, mentre la ruta es dirigia cap al Nord, s' han anat tallant diverses unitats litostratigràfiques corresponents al terciari inferior, a l'Eocè, tallant-se en ordre descendent.

Així, primer s' han tallat els nivells grisencs de calcolutites i de gresos, que pertanyen a la Formació Vallfogona, i a la Formació Campdevànol. Després s'han trobat nivells de calcolutites grisenques, de la Formació Banyoles. Igualment s'han trobat els nivells de calcolutites noduloses, alternants amb calcàries de la Formació Armàncies.

Tanmateix s'han començat a tallar uns nivells carbonatats, que pertanyen a la Formació Corones. I, finalment, a l'indret on ara som, afloren els nivells de calcàries amb alveolines, les quals pertanyen a la Formació del Cadí. I, precisament, aquest darrers materials són els que han estat explotats a l'antiga pedrera del Clot del Moro, per tal d'ésser utilitzats a l'antiga fâbrica de Ciment.

També aquí, si s'escau, cal observar el magnífic edifici de la cimentera. Aquest és un indret interessant del nostre patrimoni miner. FOTOGRAFIA 6. 


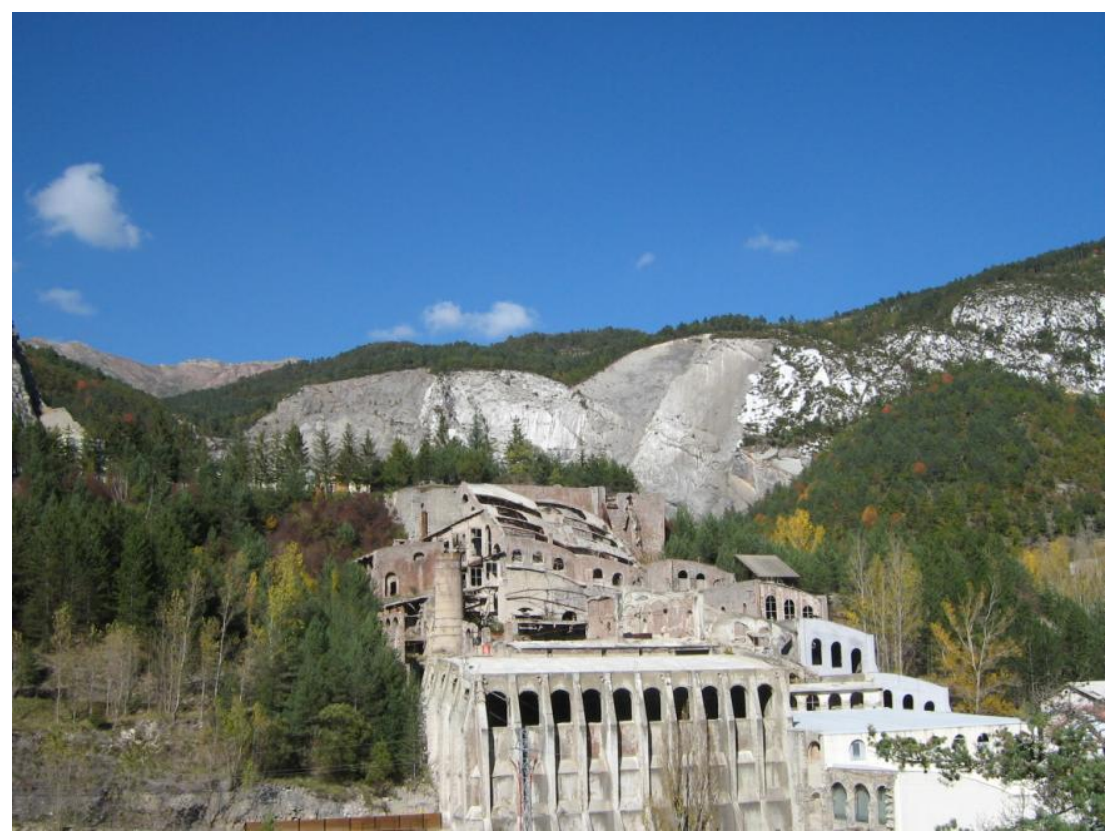

FOTOGRAFIA 6

Fabrica de cemento del Clot del Moro

\section{PARADA 7. LES FONTS DEL LLOBREGAT, (terme de Castellar de N’Hug, comarca del Berguedà). (Full 255).}

Des de l'indret de la parada anterior, ens caldrà continuar per la carretera que anem seguint, tot anant cap a Castellar de N'Hug, on s'arribarà després de fer un recorregut de $8 \mathrm{Km}$. Després, ens caldrà fer un breu recorregut de prop de $0.5 \mathrm{Km}$, per tal d'arribar fins a l'indret de les Fonts del Llobregat, el qual es troba situat a ponent del poble. En aquest indret, és on efectuarem la present aturada.

En tot aquest recorregut, des de la parada anterior, efectuat íntegrament pels materials que formen part del Mantell del Cadí, en un principi s'han anat trobant els materials cenozoics de l'Eocè i del Paleocè.

Per sota d'aquests darrers, s'han trobat els materials del Garumnià, caracteritzats per trams ocre-rogencs, i constituïts per gresos i per microconglomerats, alternants amb nivells de calcolutites grisenques.

Tot seguit, s'han començat a tallar els trams carbonatats i gresencs, pertanyents al Triàsic Inferior i al Mig; és a dir, al Buntsandstein i al Muschelkalk concretament al Muschelkalk Inferior). I, finalment, per sota dels primers, s' han començat a trobar uns nivells grisencs, que pertanyen al Permià. Aquests materials es troben integrants dintre de l'anomenat Permo-Triàsic, que molt sovint es coneix com a Permo-Bunts.

A l'indret de la parada, hi ha un aflorament dels nivells carbonatats del Muschelkalk, entre els quals hi ha una important surgència d'aigua, la qual ha donat lloc all naixement del Riu Llobregat. FOTOGRAFIA 7. 


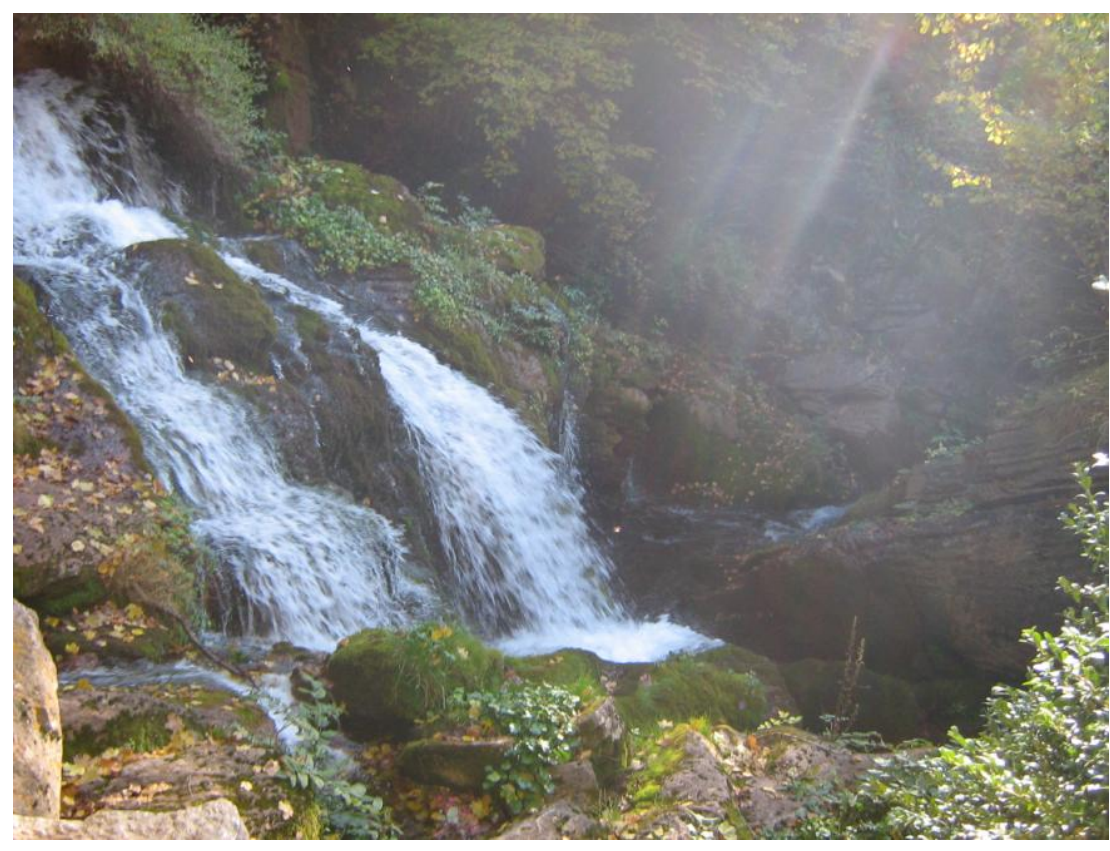

FOTOGRAFIA 7

Una de las surgències de agua, en las Fonts del Llobregat

PARADA 8 - CONDICIONAL. COLL DE LA CREUETA, (terme de la Pobla de Lillet, comarca del Berguedà). (Full 255).

Des de la parada anterior, cal retornar per la carretera que sha estat seguint fins ara, per tal d'arribar fins al Coll de la Creueta, on s'arribarà, després d'efectuar un recorregut proper als $11 \mathrm{Km}$, des de la parada anterior.

En tot aquest recorregut, $s$ han continuat trobant els materials paleozoics que formen part del Mantell del Cadí. Aquests materials es distribueixen entre el Devonià, el Carbonífer $i$ el Permià. Aquests darrers són precisament els materials que es troben a líndret de la parada.

PARADA 9. ENTRADA A ALP, (terme municipal d'Alp, comarca de la Cerdanya). (Full 216).

Des de la parada anterior, caldrà continuar cap avall, per la carretera que condueix cap a les immediacions d’Alp. En arribar-hi. Farem una nova aturada, la darrera del recorregut d'aquest itinerari.

En aquest recorregut, haurem tornat a trobar els afloraments dels gresos, calcolutites i calcàries, fonamentalment del Devonià. Aquests materials formen part del Mantell del Cadí, per on estem ara situats

Per d’altra banda, ara ens trobem situats al bell mig de la Depressió de la Cerdanya. Aquesta es troba reblerta de materials del Pliocè, del Pleistocè i de l'Holocè. 


\section{EN AQUEST INDRET FINALITZA EL RECORREGUT DE I'ITINERARI REFERÈNCIES BIBLIOGRÀFIQUES}

GUIMERÀ, J. et altri (1992).- Geologia (II), Història Natural dels Països Catalans. Vol. 2, 547 pag. Enciclopèdia Catalana, S.A., Barcelona.

IGME (1991a).- Mapa Geológico de España a escala 1:50.000 (sintesis de la cartografia existente). Full i memòria número 255 (la Pobla de Lillet). Inst. Geol. Minero de España, Minist Indústria. Madrid.

IGME (1991b).- Mapa Geológico de España a escala 1:50.000 (sintesis de la cartografia existente). Full i memòria número 256 (Ripoll). Inst. Geol. Minero de España, Minist Indústria. Madrid.

IGME (1994).- Explicació del Mapa Geologico de España, a escala 1:50.000 (full 255, la Pobla de Lillet). Inst. Tecnol. y GeoMinero de España. Minist. Indústria. Madrid.

MASACHS, V. et altri (1981).- Itineraris Geològics: Anoía, Bages, Berguedà i Solsonès. Centre d'estudis Geològics de Manresa. Caixa d'estalvis de Manresa. Manresa.

MATA-PERELLÓ, J.M. (1984).- Els minerals del Berguedà. revista Xaragall, no 3, 38 pag. Manresa.

MATA-PERELLÓ, J.M. (1991).- Els Minerals de Catalunya. Arxius de la Secció de Ciències, t. XCIII, 442 pag. Institut d'Estudis Catalans. Barcelona.

MATA-PERELLÓ, J.M. (1995).- Recerca a través de la geografia física de set comarques de la Catalunya Central. Pub. Museu de Geología de la UPC, 168 pàgines. Manresa.

MATA-PERELLÓ, J.M. (1996).- Selecció d'itineraris geològics i mineralògics pel Berguedà, i per les seves comarques veïnes. Pub. Universitat Catalana d'Estiu de la Natura. 52 pàgines. Berga.

MATA-PERELLÓ, J,M. (1997).- Recorregut de recerca geològica i mineralògica per les comarques del Berguedà i del Ripollès: des de la Pobla de Lillet a Castellar de n’Hug, a Ribes de Freser i a Queralbs. Inèdit. 14 pag. Manresa

MATA-PERELLÓ, J,M. (2007a).- Recorregut de recerca geològica, mineralògica i minera per les comarques del Berguedà i de la Cerdanya: des de Guardiola de Berguedà a Coll de Pal i a la Tossa d’Alp. Inèdit. 12 pag. Manresa

MATA-PERELLÓ, J,M. (2007b).- Recerca geològica i mineralògica per la comarca del Berguedà: des del Santuari de Queralt a Sant Quirze del Pedret i la Baells, i a la Pobla de Lillet i Riutort Inèdit. 12 pag. Manresa

MATA-PERELLÓ, J,M. (2007c).- Recorregut de recerca geològica, mineralògica i minera per les comarques del Berguedà i de la Cerdanya: des de Guardiola de Berguedà a Coll de Pal i a la Tossa d’Alp Inèdit. 7 pag. Manresa 
MATA-PERELLÓ, J,M. (2007d).- Recorregut de recerca geològica i mineralògica per les comarques del Berguedà i de la Cerdanya: des de Guardiola de Berguedà a la Pobla de Lillet, Castellar de n'Hug i a la Tossa d’Alp. Inèdit. 10 pàgines. Manresa

MATA-PERELLÓ, J.M. i FONT SOLDEVILA, J. (1995).- Itinerari geològic-mineralògic pel Berguedà. Apunts EUPM, 78 pag. Barcelona.

MATA-PERELLÓ, J.M. i SANZ BALAGUÉ, J. (1991).- Guia de determinació dels minerals. Països Catalans i Altres. Edic. Parcir. Manresa.

RIBA ARDERIU, O. Et altri. (1976).- Geografia física dels Països Catalans. Edit Ketres. Barcelona. 